\title{
PENGAJIAN KITAB KUNING DI PONDOK PESANTREN SALAFIAH ITTAQULLAH KEBUN CENGKEH KOTA AMBON
}

\author{
TEACHING OF KITAB KUNING IN PESANTREN SALAFIAH ITTAQULLAH KEBUN \\ CENGKEH, AMBON CITY
}

\author{
Idham \\ Balai Penelitian dan Pengembangan Agama Makassar \\ Jl. A.P. Pettarani No. 72 Makassar \\ Email: idhambodi73@gmail.com
}

Naskah diterima tanggal 15 oktober 2018, Naskah direvisi tanggal 23 Oktober 2018, Naskah disetujui tanggal 5 November 2018

\begin{abstract}
Abstrak
Penelitian ini bertujuan untuk menggambarkan potret termasuk kondisi rill pondok pesantren dan pengajian kitab kuning sesuai dengan undang-undang dan peraturan yang berlaku. Kemudian mengemukakan peluang dan tantangan yang dihadapi di dalam mengelola pondok pesantren Ittaqullah. Sumber data terdiri atas dua jenis yaitu data primer dan data skunder. Pengumpulan data menggunakan metode wawancara, observasi, dan dokumen. Pengolahan dan analisis data menggunakan tiga cara, yaitu penyajian data, reduksi data dan menarik kesimpulan. Hasil penelitian menunjukkan bahwa Pondok Pesantren Salafiah Ittaqullah sebagai lembaga pendidikan keagamaan Islam yang didirikan 2007 keberadaannya sangat sederhana di berbagai aspek yang hanya mengharapkanridhodan Rahmat Allah swt. Pesantren ini mengelola dua jenis pendidikan yaitu pendidikan diniyah (madrasy) yang mengintegrasikan dua pendidikan yaitu pendidikan umum dan pendidikan agama yang dikenal dengan pola pendidikan mu'allim. Pengajian kitab kuning dengan mengacu pada Peraturan Menteri Agama Nomor 13 tahun 2014 Tentang Pendidikan Keagamaan Islam. Pengajian kitab diselenggarakan melalui mengaji berbagai kitab kuning yang dilakukan dengan secara sederhana. Di dalam implementasinya terdapat peluang karena para ustad berbuat penuh keikhlasan, meskipun juga sekaligus mengalami kelemahan tentang kurangnya para ustadz yang mengajar kitab kuning, juga pengadaan kitab yang dipelajari hanya mengandal kitab yang difoto copy.
\end{abstract}

Kata kunci: pengajian, kitab kuning, pesantren ittaqullah, pendidikan keagamaan

\begin{abstract}
This study aims to describe portraits including the real condition of Islamic boarding schools and the study of kitab kuning in accordance with the laws and regulations that apply at the Islamic boarding school. Then presents the opportunities and challenges faced in managing the Ittaqullah Islamic boarding school. Data sources consist of two types, primary data and secondary data. Data collection uses interview, observation and triangulation methods. Data processing and analysis uses three methods, namely data presentation, data reduction and drawing conclusions. The results showed that the Salafiyah Ittaqullah Islamic Boarding School as an Islamic religious education institution which was established in 2007 was very simple in various aspects that only hoped for the blessings and grace of Allah swt. This pesantren manages two types of education namely diniyah education (madrasy) which integrates two educations namely general education and religious education known as mu'allim educations patterns. The study of the kitab kuning refers to the Minister of Religion Regulation No. 13 of 2014 concerning Islamic Religious Education. The study of the kitab kuning was carried out through various yellow books which were carried out in a simple manner. In its implementation there are opportunities because ustadz do full of sincerity, although also at the same time experience weaknesses about the lack of ustadz who teaches the kitab kuning, also the procurement of books that are studied only vilify the books photographed.
\end{abstract}

Keywords: recitation, kitab kuning, ittaqullah islamic boarding school, religious education 


\section{PENDAHULUAN}

$\mathrm{P}$ ondok pesantren adalah lembaga pendidikan keagamaan tertua di Indonesia yang tumbuh bersamaan dengan masa penyiaran agama Islam (Ibrahim, 2018). Hingga saat ini pondok pesantren yang pada umumnya didirikan oleh kiai dengan kemandirian dan keikhlasan masih tetap eksis dan berkembang di tengah-tengah masyarakat. Dinamika keberadaan pondok pesantren menunjukkan bahwa lembaga ini tetap konsisten melaksanakan fungsi utamanya, yaitu menyiapkan generasi yang menguasai ilmu-ilmu keislaman tafaqqahu fi ad-din sebagai kader ulama, mubalig atau pendidik yang sangat dibutuhkan oleh masyarakat.

Pondok pesantren merupakan bentuk pendidikan keagamaan Islam yang awalnya berbentuk lembaga non formal tradisional di Bumi Nusantara. Pondok pesantren merupakan salah satu model pendidikan keagamaan Islam yang sudah lama mengakar dalam kehidupan masyarakat Indonesia. Pondok pesantren tumbuh di Nusantara sebagai upaya para ulama dalam mengembangkan pendidikan keagamaan Islam kepada masyarakat sehingga pondok pesantren merupakan tempat yang sangat trategis untuk membentuk generasi penerus yang tafaqqahu fi ad-din (Idham, 2017).

Di antara lembaga pendidikan yang ada di Indonesia pesantren merupakan sistem pendidikan tertua sebagai hasil proses sejarah panjang. Keberadaan dan kiprahnya sebagai lembaga sosial kemasyarakatan yang bergerak di bidang pendidikan, pengajaran dan dakwah untuk mencetak kader ulama yang tafaqqahu fi ad-din (Rasyid dan Idham, 2017), memberi andil dalam pembentukan dan pembinaan mental spiritual serta karakter terutama bagi masyarakat pinggiran.

Pondok pesantren telah berperan dalam mengembangkan budaya dan peradaban (transformasi kultural) yang menyeluruh dalam kehidupan masyarakat Nusantara (Ahmad, 2013). Pesantren hadir sebagai jawaban untuk menegakkan nilai ajaran agama melalui pendidikan keagamaan dan mengayom dan memerikan dukungan kepada kelompok yang bersedia menerima ajaran Allah dan Rasul-Nya.

Sejak awal pondok pesantren salafiah merupakan salah satu model pendidikan yang mengakar dalam kehidupan masyarakat Indonesia dan merupakan cikal bakal sistem pendidikan keagamaan Islam pertama khas pribumi (Idham,
2016). Kekhasannya tidak saja karena keberadaan yang sudah lama, tetapi juga karena kultur, metode dan jaringan yang diterapkan (Ismail, 2016). Kurikulum di pondok pesantren terutama pondok pesantren salafiah lebih banyak berorientasi pada kapasitas santri agar menguasai ilmu agama secara komprehensif yang bersumber dari kitab-kitab klasik.

Berdasarkan latar belakang tersebut maka rumusan masalah penelitian ini: Apa dan bagaimana keberadaan pondok pesantren Ittaqullah?, bagaimana potret pengajian kitab kuning di pondok pesantren Ittaqullah?, dan bagaimana peluang dan tantangan dalam pengajian kitab kuning di pondok pesantren Ittaqullah?

Penelitian ini bertujuan untuk menggambarkan potret termasuk kondisi riil pondok pesantren dan pengajian kitab kuning sesuai dengan undang-undang dan peraturan yang berlaku dan diberlakukan di pondok pesantren. Kemudian mengemukakan peluang dan tantangan yang dihadapi pondok pesantren Ittaqullah. Melalui penelitian ini, diharapkan menjadi masukan bagi penentu kebijakan dalam rangka pengambilan keputusan tentang pembangunan di bidang pendidikan keagamaan Islam di pondok pesantren terutama yang terkait dengan pengajian kitab kuning.

\section{Tinjauan Pustaka}

Secara yuridis pondok pesantren adalah salah satu lembaga pendidikan tertua yang merupakan produk Indonesia maka lembaga pendidikan ini juga mengacu kepada: Undang-Undang Dasar 1945, pasal 31 ayat (3), bahwa pemerintah mengusahakan dan menyelenggarakan satuan Sistem Pendidikan Nasional yang meningkatkan keimanan dan ketakwaan serta akhlak yang mulia.

Undang-Undang Sistem Pendidikan Nasional Nomor 20 Tahun 2003, pasal 30 ayat (1), (2), (3). Ayat (1) pendidikan keagamaan diselenggarakan oleh pemerintah dan/atau kelompok masyarakat dari penganut agama, (2) fungsi pendidikan keagamaan, ayat (3) penyelenggaraan pendidikan keagamaan melalui jalur pendidikan formal, nonformal dan informal. Pondok pesantren secara, a) filosofi adalah bagian dari pendidikan keagamaan yang mampu membentuk manusia Indonesia yang beriman dan bertakwa kepada Tuhan Yang Maha Esa, serta berakhlak mulia, b) historis adalah bagian integral dalam Sistem Pendidikan Nasional dan c). Secara yuridis tercakup dalam ketentuan undangundang Sistem Pendidikan Nasional. 
Peraturan Pemerintah Republik Indonesia Nomor 55 Tahun 2007 tentang pendidikan dan pendidikan keagamaan. Bab I pasal 1 ayat (2), pendidikan keagamaan adalah pendidikan yang mempersiapkan peserta didik untukmengetahui, ahli dan menjalankan ajaran agamanya, ayat (4) Pondok pesantren adalah lembaga pendidikan keagamaan Islam berbazis masayarakat yang menyelenggarakan pendidikan diniyah atau secara terpadu dengan jenis pendidikan lainnya. Bab III Pasal 26 ayat (1), (2), (3). Ayat (1) Pesantren menyelenggaakan pendidikan dengan tujuan menanamkan keimanan dan ketakwaan kepada Allah SWT, akhlak mulia, ayat (2) pesantren menyelenggarakan pendidikan diniyah atau secara terpadu dengan jenis pendidikan lain, ayat (3) peserta didik dan/atau pendidik di pesantren yang diakui keahliannya di bidang ilmu agama memiliki ijazah pendidikan formal dapat menjadi pendidik mata pelajaran/kuliah pendidikan agama disemua jalur, jenjang, dan jenis pendidikan yang memerlukan.

Peraturan Menteri Agama tentang Pendidikan Keagamaan Islam, Bab I Pasal 1 ayat (2) Pondok pesantren adalah lembaga pendidikan Keagamaan Islam yang diselenggarakan oleh masyarakat.

Peraturan Pemerintah Nomor 19 Tahun 2005 tentang Standar Nasional Pendidikan.

Peraturan Menteri Agama (PMA) Nomor 13 Tahun 2014, BAB I, Pasal I, Ayat (2), (3), (4), (5), (7). Ayat (2) pondok pesantren yang selanjutnya disebut (pesantren) adalah lembaga pendidikan keagamaan Islam yang diselenggarakan oleh masyarakat dan yang menyelanggarakan satuan pendidikan peesantren dan/atau secara terpadu menyelenggarakan jenis pendidikan laainnya. (3) Kitab kuning adalah kitab keislaman berbahasa Arab yang menjadi rujukan tradisi keilmuan Islam di pesantren. (4) Dirasah islamiyah adalah kajian tentang ilmu agama Islam yang tersusun secara sistematik, terstruktur dan terorganisasi (madrasy). (5) Pola pendidikan mu'alliminadalah sistem pendidikan pesantren yang bersifat integratif dengan memadukan ilmu agama Islam dan ilmu umum dan bersifat komperhensif dengan memadukan intra, ekstra, dan kokurikuler. (7) pendidikan diniyah formal adalah lembaga pendidikan keagamaan Islam yang diselenggarakan oleh dan berada di dalam pesantren secara berstruktur dan berjenjang pada jalur pendidikan formal.

\section{Metode Penelitian.}

Penelitian ini menggunakan metode pengumpulan data yang lazim digunakan dalam penelitian kualitatif yaitu wawancara (Cresswell, 1994). Teknik wawancara dilakukan dengan informan dalam rangka menelusuri dan mendapatkan informasi sejarah pondok dan penggunaan kitab kuning di pondok Pesantren Ittaqullah. Teknik wawancara digunakan bersamaan dengan teknik observasi/pengamatan serta dokumentasi. Analisis data telah dilakukan sejak penelitian ini berlangsung hingga berakhirnya proses pengumpulan data. Karena penelitian ini merupakan penelitian kualitatif, maka analisis data dilakukan dengan analisis kualitatif deskriptif.

\section{PEMBAHASAN}

\section{Pondok pesantren Ittaqullah.}

Sebelum mengemukakan pondok pesantren Ittaqullah maka dikemukakan sejarah pondok pesantren secara umum. Pertumbuhan dan perkembangan pesantren tidak terlepas pada sejarah masuknya Islam di Indonesia. Pendidikan Islam di Indonesia bermula ketika orang menganut Islam karena ingin mengetahui secara mendalam ajaran Islam yang dianutnya, baik tentang tatacara beribadah, baca al-Qur'an dan kajian untuk mengetahui ajaran Islam lebih luas dan mendalam. Untuk itu mereka belajar di rumah, surau, langgar atau masjid. Di tempat inilah seorang mualaf dan anak-anak belajar membaca al-Quran dan ilmu tentang Islam dan dalam perkembangannya untuk lebih memperdalam yang memotivasi timbulnya pesantren yang merupakan tempat untuk melanjutkan pembelajaran agama setelah tamat belajar di surau, langgar atau masjid.

Model pendidikan pesantren ini berkembang di seluruh Indonesia dengan nama dan corak yang sangat bervariasi, di Jawa di sebut pondok pesantren, di Aceh dikenal rangkang, di Sumatera Barat dikenal dengan nama surau, namun sekarang secara umum terkenal dengan nama pondok pesantren. Itulah sebabnya sehingga pesantren dikenal sebagai lembaga pendidikan pribumi tertua di Indonesia.

Pondok Pesantren Salafiyah Ittaqullah adalah sebuah lembaga pendidikan keagamaan Islam yang didirikan pada 3 Desember 2007 dengan NSPP. 502381710001 oleh Ustadz Hi. Djawali Laitupa, MA dan Ibu Hj. Rahmah Henaulu,S.Pd.I. Pondok pesantren ini terletak di Jalan Kebun Cengkeh RT. 03 RW. 09 Nomor 10, Kelurahan Batu Merah, 
Kecamatan Sirimau Kota Ambon Provinsi Maluku.

Tujuan pendirian pondok pesantren salafiah Ittaqullah adalah sebagai upaya untuk mencetak manusia yang tafaqqahu fi ad-din, menjadi kader pemimpin umat/bangsa. Mengupayakan santri yang memiliki jiwa keikhlasan, kesederhanaan, kemandirian, ukhuwah Islamiyah, kebebasan berfikir dan berperilaku sesuai dengan tuntunan Al-Quran dan Sunnah untuk mencapai ketaqwaan kepada Allah SWT.

Seteleh yayasan Ittaqullah terbentuk maka pengurus yayasan sepakat untuk mendirikan pendidikan keagamaan Islam sesuai dengan Peraturan Menteri Agama Republik Indonesia Nomor 13 Tahun 2014 khususnya bab I Pasal 1 ayat (2) pondok pesantren yang selanjutnya disebut pesantren, ayat (4) dirasah Islamiyah (madrasy), dan ayat (5) dengan pola pendidikan mu'allimin.

Peraturan tersebut menunjukan bahwa yayasan Ittaqullah mengelola pondok pesantren dan pendidikan dirasah Islamiyah (madrasy) dengan pola pendidikan mu'allimin. Pola pendidikan mu'allimin adalah sistem pendidikan pesantren yang bersifat integratif dengan memadukan ilmu agama Islam dan ilmu umum dan bersifat komperhensif dengan memadukan intra, ekstra, dan kokurikuler.

\section{Pengajian Kitab Kuning di Pondok Pesantren Ittaqullah.}

Implementasi pengajian kitab kuning di pondok pesantren Ittaqullah dikemukakan melalui unsur pesantren sesuai dengan PMA (Peraturan Menteri Agama Nomor 13 Tahun 2014, bab II pasal 5, bahwa pesantren wajib memiliki unsur-unsur pesantren yang terdiri atas kiai atau sebutan lain yang sejenis, seperti santri, pondok atau asrama pesantren, masjid atau mushalla, pengajian dan kajian kitab atau dirasah Islamiyah dengan pola pendidikan mu'allimin.

Sedangkan unsur pesantren ini dikenal dengan istilah komponen pendidikan dalam Sistem Pendidikan Nasional dan sesuai pula dengan pendapat pakar pendidikan. Unsur pesantren atau komponen pendidikan tersebut adalah pendidik, murid, kurikulum, materi pembelajaran, metode, sarana prasarana dan sistem evaluasi. Pembahasan pengajian kitab kuning di pondok pesantren salafiah Ittaqullah digambarkan melalui unsur pesantren/komponen pendidikan, yaitu pendidik, peserta didik, kurikulum, metode, sistem evaluasi, dan sarana prasarana.

\section{Kiai/Pendidik}

Di dunia pendidikan seorang pendidik terkenal dengan berbagai istilah sesuai dengan istilah yang berlaku disuatu daerah seperti ustadz, kiai (Jawa, Sulawesi), Tuan Guru (Lombok), Andreguru (Bugis), Anrongguru (Makassar), Anangguru (Mandar). Menurut Muhaimin (2017) ada yang menggunakan istilah mu'allim, mrabbiy, mursyid, mudarris, dan mu'addib. $\mathrm{K}$ ata ustadz (Arab) biasa digunakan gelaran seorang profesor (guru besar dari Mesir).

Sedangkan di pondok pesantren Ittaqullah menggunakan istilah ustadz untuk KHi. Djawali Laitupa, sedangkan pendidik yang lain dipanggil dengan kakak. Kakak yang mengabdi di pondok pesantren Ittaqullah terdiri atas 6 orang, Nur Saba Laitupa, SalifahBellatu, Sarina Sari Kalauw, Hamidah Umasugi, Ahmad Laitupa dan Saleh Moni. Adapun kakak yang mengajarkan kitab kuning adalah kakak Shaleh Moni.

\section{Santri}

Santri menurut Peraturan Menteri Agama $13 / 2014$, santri adalah peserta didik yang bermukim di pondok atau asrama pesantren. Di dunia pendidikan umum dikenal dengan istilah siswa dan peserta didik kalau di pondok pesantren terkenal dengan istilah santri. Santri yang tinggal di asrama pondok pesantren Ittaqullah sebanyak 62 orang. Adapun santri di pondok pesantren Ittaqullah berasal dari orang tua yang kurang mampu.

\section{Kurikulum}

Kurikulum secara tekstual berasal dari bahasa Yunani currereyang berarti jarak tempuh lari. Secara kontekstual yaitu jarak tempuh berlari yang digunakan dalam bidang olah raga mulai dari star hingga finish. "kemudian pengertian ini diterapkan di bidang pendidikan" (Muhaimin, 2007: 1).

Di dunia pondok pesantren kurikulum dikenal dengan manhaj(bahasa Arab), kurikulum dalam perspektif pendidikan keagamaan Islam berdasarkan Peraturan Menteri Agama Nomor 13 Tahun 2014, bab I pasal 1, poin 13, bahwa kurikulum adalah seperangkat rencana dan pengaturan mengenai tujuan, isi, bahan pelajaran, dan cara yang digunakan sebagai pedoman penyelenggaraan kegiatan pembelajaran untuk mencapai tujuan pendidikan tertentu.

Kurikulum dalam perspektif pendidikan agama berfungsi sebagai penjabaran dan pelaksana dalam pembelajaran baik dalam hal isi, metode 
maupun evaluasi. Sedangkan kurikulum yang menekankan pada proses atau pengalaman bertolak dari asumsi bahwa pesera didik sejak dilahirkan telah memiliki potensi, baik potensi berpikir, berbuat, memecahkan masalah, maupun untuk belajar dan berkembang sesuai kondisi yang ada, karenanya kurikulum biasanya di tentukan oleh sekelompok ahli di susun secara sistematis dan logis sesuai dengan disiplin ilmu yang dianggap telah mapan.

Kurikulum dalam konteks pendidikan keagamaan Islam idealnya tidak disusun secara sentralistik karena walaupun agama berlaku universal, tetapi problem kehidupan keagamaan Islam menjadi lokal sektoral. Kementerian Agama hanya memberi rambu-rambu di dalam kurikulum pendidikan keagamaan Islam dan tidak sampai menyentuh kesubstansi materi, sehingga kurikulum yang disusun Kementerian Agama harus terbuka sehingga sangat memungkinkan bagi para pendidik melakukan improvisasi terhadap kurikulum tersebut.

Kurikulum pengajian kitab kuning di pondok pesantren Ittaqullah ditentukan oleh ustadz dan kakak termasuk kitab kuning yang dipelajari dan jadwal pengajiannya. Adapun jadwal pengajian kitab kuning di pondok pesantren Salafiah Ittaqullah, yaitu: Senin, Sorofa. Selasa, Amsilah. Rabu, Nahwu. Kamis, Syarah. Jum'at, Mutammimah. Sabtu, Safinah. Pengajian dilakukan pada setiap subuh (05.00) dilakukan oleh kakak Saleh Moni. Kadangkala pengajian kitab kuning bulughu al-maram oleh Muhamad Laitupa (waktu beliau masih hidup).

\section{Metode Pembelajaran}

Metode secara teks berasal atas kata meta yang berarti melalui dan hodos yang berarti jalan, berarti metode adalah jalan yang dilalui. Secara kontekstual metode adalah istilah yang digunakan untuk mengungkapkan pengertian cara yang paling tepat dan cepat dalam melakukan sesuatu. Metode dalam perspektif pendidikan keagamaan Islam bahwa "metode adalah cara yang paling tepat dan cepat dalam mengajarakan agama Islam (Tafsir, 2007: 9)

Secara teoritis seorang pendidik harus mampu menerpakan teori di dalam proses pembelajaran karena metode sangat menentukan keberhasilan suatu pembelajaran. Metode yang digunakan dalam proses pembelajaran oleh pendidik yang mengajar pada satuan pendidikan umum harus sesuai dengan Undang-UndangSisdiknas 20/2003 dan PP. 55/2007 yaitu metode pembelajaran umum. Umum karena dapat digunakan dalam pembelajaran apapun dan metode tersebut adalah metode ceramah, tanya jawab, diskusi, demonstrasi, penugasan, resitasi dan karya wisata.

Metode pembelajaran di pondok pesantren terbagi atas dua berdasarkan PMA 13/2014 pasal 15, yaitu pembelajaran kitab kuning dan pembelajaran dirasah Islamiyah. 1) pembelajaran kitab kuning dilakukan dengan menggunakan metode sorogan (individual), metode bandongan, metode bahtsu al-masail dan metode lainnya, (2) pembelajaran dirasah Islamiyah dengan pola pendidikan mu'allimin dilakukan dengan metode klasikal, terstruktur dan berjenjang sesuai dengan struktur kurikulum yang ditetapkan oleh pesantren.

Metode bila dilihat pada perspektif pendidikan keagamaan Islam banyak kesamaannya dengan aliran filsafat pragmatisme. Menurut AlGazali bahwa "metode pelajaran harus berprinsip pada child centered yang mementingkan anak didik dari pada pendidik sendiri" (Rahim, dkk, 2001: 21) Implementasi dari prinsip metodologis tersebut merupakan penggunaan metode tauladan dan pendidikan keagamaan Islam mencakup pembinaan terhadap kognitif, afektif dan psikomotoris bagi peserta didik. Sedangkan menurut An-Nawawi, bahwa "di dalam Al-Qur'an dan hadis terdapat metode pendidikan yang sangat menyentuh perasaan, mendidik jiwa dan membangkitkan semangat dan mampu menggugah puluhan ribu kaum muslim untuk membuka hati umat manusia menerima tuntutan Tuhan" (Rahim, dkk. 2001: 21).

Metode yang dimaksud, adalah: 1) metode hiwar qirani dan nabawi, yaitu dialog antara dua pihak atau lebih tentang suatu tema dan sengaja diarahkan pada suatu tujuan yang dikehendaki, 2) metode kisah qur'ani dan nabawi, yaitu metode kisah, 3) metode Amtsal, metode yang ditampilkan hampir sama dengan metode kisah, yaitu dengan ceramah atau membaca teks, 4) metode teladan, yaitu memberikan keteladan pada pesereta didik baik seara formal maupun informal, 5) metode pembiasaan, yang intinya adalah pengulangan, antara lain bila pendidik masuk ke ruang kelas mengucapkan salam, 6) metode ibrah dan mauidzah, adalah metode kisah yang bisa menyentuh kalbu sehingga orang mampu menerima hikmah dari kisah dan mengimplementasikan dalam kehidupan. Kisah dalam Al-Qur'an dan Al-Hadis bukan hanya aspek historisnya, tetapi memperoleh hikmah dan diimplementasikan dalam kehidupan. Metode 
mauidzah, merupakan metode yang efektif untuk menyentuh kalbu, mengandung makna nasehat yang lembut sehingga diterima secara ikhlas, dan 7) metode targhib dan tahrib, yaitu metode yang didasarkan atas fitrah manusia yang menginginkan kesenangan dan menghindari kepedihan.

Metode pembelajaran tradisional yang menjadi ciri khas di pondok pesantren salafiah, menurut A. Qadri (2004) adalah metode "sorogan, wetonan/bandongan, metode musyawarah (bahstu al-masail, pengajian pasaran, metode hafalan (muhafzah), metode demonstrasi/ parkatek ibadah, masa pembelajaran dan syahadah".

Di pondok pesantren Ittaqullah tidak mengenal metode pembelajaran baik metode umum atau metode dalam istilah (bahasa) Jawa, maupun metode yang digunakan oleh An Nawawi. Sebenarnya mereka lakukan semua metode tersebut secara pasif hanya mereka tidak menggunakan istilah tersebut, artinya mereka melakukan pembelajaran apa adanya dan proses pembelajaran berjalan sesuai dengan kebiasaan yang berlaku dan diberlakukan pada pondok pesantren Ittqullah dan yang terpenting bagi mereka tujuan pendidikan tercapai.

\section{Sistem Evaluasi}

Padalembaga pendidikan dikenal adanya suatu sistem evaluasi berupa evaluasi manajemen sekolah dan evaluasi pembelajaran. Di dunia pendidikan sistem evaluasi dikenal dengan pengawasan dan supervisi, walaupun dua istilah ini berbeda namun keduanya merupakan salah satu fungsi penting dalam manajemen satuan pendidikan. Matry (2008: 358) mengemukakan bahwa "supervisi memiliki kaitan makna dengan pengawasan yaitu sama-sama mengandung unsur evaluasi, namun dalam praktek keduanya memiliki perbedaan mendasar terutama mengenai sasaran dan metode kerjanya".

Perbedaan antara supervisi dan pengawasan yaitu: a) pengawasan dan evaluasi aksentuasinya pada monitoring dengan tjuan pengendalian manajemen sekolah, b) supervisi, aksentuasinya pada penilaian dengan tujuan pembinaan dan pengembangan secara provesional terhadap proses pembelajaran. Supervisi dalam implementasinya terbagi tiga yaitu "supervisi akademik, klinik dan supervisi administratif” (Matry, 2008: 358) Supervisi tersebut adalah: 1) supervisi akademik, sasarannya pada proses pembelajaran yang sedang berlangsung, 2) supervisi klinik adalah aspek perbaikan secara fisik, dan 3) supervisi administrasi yang menitikberatkan pada aspek administrasi yang berfungsi sebagai pendukung proses pembelajaran.

Tujuan supervisi adalah memotivasi siapapun dan apapun istilahnya sebagai pelaksana supervisi berkewajiban melaksanakan pengawasan dan supervisi secara terencana, terkoordinasi, terarah pada semua aspek kegiatan pada satuan pendidikan dan pengawasan. Di dunia pendidikan mengenal sistem evaluasi "evaluasi normatif dan evaluasi sumatif dan dalam implementasinya berbeda diantara keduanya". (A.Qadri, 2004: 18)

Tulisan ini hanya mengemukakan sistem evaluasi pembelajaran karena di dunia pondok pesantren salafiah hanya mengenal evaluasi pembelajaran, yaitu evaluasi untuk menilai keberhasilan penguasaan bahan pembelajaran oleh santri.

Evaluasi di pondok pesantren Ittaqullah mutlak dilakukan oleh ustadz, kakak pada setiap pembelajaran karena tidak akan pindah masalah pembelajaran pada pembelajaran berikutnya sebelum menguasai pembelajaran sebelumnya karena tujuan evaluasi adalah penguasaan, pemahaman santri tentang pengajian kitab kuning yang diberikan oleh ustadz/kakak selama proses pembelajaran, misalnya kakak Saleh Moni mengajar kitab sorofa (Ula) ketika santri belum menguasai tentang delapan (8) binaa'un, maka santri tersebut tidak akan diizinkan mengikuti pengajian kitab amsilah (ula) yang merupakan kitab yang akan dipelajari setelah sorofa, demikian seterusnya.

\section{Sarana Prasarana}

Sarana dan prasarana pendidikan menurut Matry (2008: 115) "sarana adalah peralatan dan perlengkapan yang secara langsung dipergunakan untuk menunjang proses pendidikan. Prasarana adalah fasilitas secara tidak langsung menunjang proses pembelajaran". Sarana adalah perlengkapan yang secara langsung dipergunakan dalam proses pembelajaran. Sarana di pondok pesantren Ittaqullah adalah pendidikan Diniyah dan pondok pesantren (pengajian kitab kuning) menggunakan gedung berlantai empat lengkap sarana pendidikan yang lain.

Prasarana yang terdapat di pondok pesantren adalah di sebelah Selatan gedung pondok pesantren Ittaqullah adalah Jalan Raya Kebun Cengkeh yang menghubungkan terminal Batu Merah menuju IAIN Ambon, sebelah barat adalah bagunan rumah atau rumah tetangga (masyarakat), dan sebelah utara dan timur dikelilingi oleh lingkungan yang terdiri atas taman dan pepohonan. 


\section{Peluang dan Tantangan Eksistensi Pesantren Ittaqullah}

Keikhlasan bagi pendiri yayasan, para pengasuh/ustadz/kakak di pondok pesantren salafiah Ittaqullah menjadi peluang tersendiri, hal ini dapat dilihat pada motivasi pendirian yayasan dan pondok pesantren Ittaqullah hanya bermodalkan keikhlasan dan idealisme pendiri yayasan ustadz KHi. Djawali Laitupa, ustadzah $\mathrm{Hj}$. Rahmah Henaulu mendatangi lingkungan, desa atau kampung-kampung sekitar pondok pesantren untuk mencari anak-anak orang yang tidak mampu (tua), dengan pensyaratan a) orang tuanya ikhlas menyerahkan anaknya untuk dibina di pondok pesantren, b) anak diharapkan kesabaran, dan c) anak diharapkan memiliki kemauan untuk belajar.

Para santri diasramakan pada asrama santri dan mereka dibina pada pondok pesantren salafiah dan ketika mereka usia sekolah mereka akan disekolahkan pada diniyah ula, wustha dan kemudian melanjutkan pendidikan keagamaan pada dirasah Islamiyah dengan pola pendidikan mu'allimin (MI, MTs, MA) pada pondok pesantren Ittaqullah.

Ustadz/kakak mengandalkan pengabdian karena Allah SWT, mereka tidak mengharapkan jasa, namun mereka tetapdiberikan jasa sesui dengan kemampuan pondok pesantren, misalnya bagi yang kuliah dibayarkan SPP dan transpotasi kalau pergi kuliah. Hal tersebut terjadi karena pengabdi di pondok pesantren adalah keluarga dan kerabat.

Masyarakat mendukung segala kegiatan pondok pesantren Ittaqullah karena keberadaan pondok pesantren sangat diharapkan masyarakat untuk memenuhi kebutuhan spiritual mereka. sekurang-kurangnya memimpin doa dalam setiap upacara lingkaran hidup. Oleh sebab itu, komunitas pondok pesantren Ittaqullah selalu dipanggil oleh masyarakat apabila ada acara ritual siklus hidup mereka.

Faktor penghambat dalam keberadaan pondok pesantren Ittaqullah adalah kurangnyaustadz, kakak terutama pada pengajian kitab kuning sejak awal keberadaan pengajian kitab kuning hanya memiliki seorang kakak Muhamad Laitupa pernah mengajar kitab bulugulmaram dilakukan pada setiap Jum'at sore (ba'dalAtsar) hingga 2011. Sejak 2011 hingga 2015 pernah fakum pengajian kitab karena sesuatu alasan a). Kakak Muhamad Laitupa pindah tempat tinggal yang jauh dari pondok pesantren. b). Sepeninggal Muhamad Laitupa terjadi krisis kakak karena luaran dari pengajian kitab belum matang, masih standar dan belum siap pakai.c). Generasi muda Ambon kurang memiliki kemauan belajar bahasa Arab dan kurang di antara mereka menekuni pengajian kitab kuning. d). Ketersediaan kitab kuning sangat kurang, mereka hanya kitab kuning yang di foto copy. e). Pendidik/kakak yang berasal dari luar terutama dari pondok pesantren di Jawa kurang yang mau mengabdi di pondok pesantren Ittaqullah.

\section{PENUTUP}

Pondok Pesantren Salafiyah Ittaqullah adalah lembaga pendidikan keagamaan Islam yang didirikan 2007 yang bertujuan untuk mencetak manusia yang tafaqqahu fi ad-din. Keberadaannya sangat sederhana diberbagai aspek, yang hanya mengharapkan Rahmat Allah SWT. Pondok pesantren Ittaqullah mengelola pendidikan keagamaan Islam, yaitu Dirasah Islamiyah (madrasy) dengan pola pendidikan mu'allimin. Pada pendidikan muallimin membina madrasah Ibtidaiyah, Tsanawiyah dan Aliyah. Oleh karena sistem pendidikan keagamaan Islam bersifat integratif yang memadukan antara pendidikan keagamaan Islam dan pendidikan umum maka implementasinya mengacu kepada beberapa regulasi, antara lain undang-undang Sistem Pendidikan Nasional Nomor 20 Tahun 2003, PP No. 55 Tahun 2007 tentang pendidikan agama dan pendidikan keagamaan, dan PMA Nomor 13 tahun 2014 Tentang Pendidikan Keagamaan Islam.

Implementasi pengajian kitab kuning di pondok pesantren Ittaqullah dibahas melalui unsur pesantren atau komponen pendidikan, yaitu Pendidik, dikenal dengan ustadz bagi pimpinan pondok Djawali Laitupa dan kakak bagi enam orang pendidik yang lainnya. Terdiri atas 62 orang santri. Kurikulum, menggunakan kurikulum pendidikan keagamaan Islam dan kurikulum pendidikan umum sejalan dengan salah satu pembelajaran modern yang di kenal dengan pendekatan pembelajaran tuntas (mastery learning), yaitu mempelajari sampai tuntas (khatam) kitab kuning sebagai rujukan. Metode pembelajaran yang digunakan adalah metode bandongan dan digunakan secara pasif oleh kakak dengan mentransfer metode yang digunakan oleh ustadz tempat ketika menimba ilmu pengetahuan.

Sistem Evaluasi. Kakak melakukan Evaluasi normatif secara pasif, yaitu menilai penguasaan santri terhadap pembelajaran yang sudah dan 
sedang berlangsung dalam jangka waktu yang relatif pendek dan pada akhir pembelajaran kakak menilai keberhasilan penguasaan santri terhadap proes pembelajaran (pokok bahasan). Memiliki 2 sarana pendidikan masing-masing terdiri atas 4 lantai, a) sebuah bangunan sebagai tempat penyelenggaraan dirasah Islamiyah dengan pola pendidikanmu'allimin yaitu Madrasah Ibtidaiyah, Madrasah Tsanawiyah dan Aliyah. b) Sebuah bangunan sebagai tempat aktifitas dan proses pengajian kitab kuning bagi santri diniyah, ula, dan wustha.

Ketersediaan bangunan untuk aktifitas pendidikan keagamaan Islam, keikhlasan bagi kakak pada pengajian kitab kuning dan melaksanakan tugas tanpa mengharapkan jasa. Bagi peserta didik dirasah Islamiyah memperoleh dana Boss, adalah beberapa kelebihan yang dimiliki pesantren Ittaqullah. Sedangkan tantangan yang dihadapi adalah hanya dua orang yang bersedia mengabdi untuk kepentingan pengajian kitab kuning di pondok pesantren Ittaqullah. Kitab kuning yang menjadi pegangan hanyalah foto copy yang disiapkan oleh pembina (kakak).

\section{UCAPAN TERIMA KASIH}

Sejatinya, artikel ini hadir di hadapan sidang pembaca budiman, tak lepas dari kontribusi beberapa pihak, diantaranya yang dapat penulis sebutkan (tanpa bermaksud menafikan bantuan pihak lainnya) pimpinan, para asatidz, dan kalangan santri pondok pesantren Salafiyah Ittaqullah. Atas kontribusi mereka tersebut, penulis mengapresiasi dengan tulus melalui ucapan terima kasih yang tak terhingga.

\section{DAFTAR PUSTAKA}

A.Qadri A. Azizy.2004. Profil Pondok pesantren Mu'adalah, Jakarta: Depertemen Agama RI, Direktorat Jenderal Kelembagan dan Pondok Pesantren, Proyek Peningkatan Pondok Pesantren.

Ahmad, Abd. Kadir. 2013. Ulama Bugis. Makassar: Indobis

Amrulloh, M. Zulfikar. 2015. Strategi Pembelajaran Kitab Kuning di Sekolah Tinggi Ilmu Kitab Kuning An-Nur 2 Bululawang Malang (tesis). Malang: Program Magister Pendidikan Agama Islam Sekolah Pascasarjana Universitas Negeri Maulana Malik Ibrahim Malang.

Ashof, Muhammad. 2017. Pelaksanaan Pembelajaran Kitab Kuning Dengan Methode Ibtida’i di Pondok Pesantren Al Huda Doglo Candigatak Cepogo Boyolali Tahun 2016-2017 (skripsi). Surakarta:
Fakultas Tarbiyah dan Keguruan Institut Agama Islam Negeri Surakarta.

Behri, Mat. 2017. "Program Akselerasi Baca Kitab Kuning di Majelis Musyawarah Kutubuddiniyah (M2KD) PP. Mambaul Ulum Bata-Bata DS. Panaan Kec. Palengaan Kab. Pamekasan', dalam jurnal Fikrotuna: Jurnal Pendidikan dan Manajemen Islam, 6(2): 678-694

Cahyati, Nur. 2012. Pembelajaran Kitab Kuning di Kelas I'daddy Pondok Pesantren Al-Luqmaniyyah Yogyakarta (Study Komparasi Efektifitas Metode Bandongan dengan Metode Sorogan) (skripsi). Yogyakarta: Fakultas Tarbiyah dan Keguruan Universitas Islam Negeri Sunan Kalijaga Yogyakarta.

Cresswell, Jhon W. 1994. Research Design, Qualitative and Quantitative Approaches. California: Thousand Oaks.

Departemen Pendidikan Nasional, Undang-Undang RI No. 20 Tahun 2003 Tentang Sistem Pendidikan Nasional (Sisdiknas). Bandung: Fokus Media.

Depianti, Lia. 2017. "Proses Sosialisasi Belajar Kitab Kuning Pada Santri Tingkat Wustha di Pondok Pesantren Salafiyah Nurhidayah Desa Bencah Kelubi Kecamatan Tapung Kabupaten Kampar, dalam jurnal JOM FISIP, 4(1): 1-15.

Djamarah, Syaiful Bahri Dkk,. 1993.Strategi Belajar Mengajar.Banjarmasin: Penerbit Rineka Cipta.

Hanani, Nurul. 2017. "Manajemen Pengembangan Pembelajaran Kitab Kuning", dalam jurnal Realita, 15(2): $1-25$

Ibrahim, Rustam. 2018. "Pesantren dan Pendidikan Kebangsaan: Studi Tentang Buku al-Difảani al-Wathan min Ahammi al-Wajibat 'ala Kulli Wahidin Minna Karya Kiai Muhammad Said, dalam Jurnal Miqot, 42(1): 148-170.

Idham. 2016. "Empowerment of Santri in Reality and Recollection: Study in Pesantren Hubulo, Gorontalo", dalam Jurnal Pendidikan Islam, 5 (2): 235-260.

Idham. 2017. "Pola Pengkaderan Ulama di Sulawesi Selatan (Studi pada Program Ma’had Aly Pondok Pesantren As'adiyah Sengkang Kabupaten Wajo)", dalam Jurnal Al-Ulum, 17(2): 439-458.

Inderasari,Elen dan DwiKurniasih.2018. "Kedwibahasaan Sebagai Upaya Pemahaman dalam Pembelajaran Kitab Kuning di Pondok Pesantren Mahasiswa Darussalam, dalam Jurnal Trasformatika: Jurnal Bahasa, sastra, dan Pengajarannya, 2(1): 36-49.

Ismail, Arifuddin. 2016. Tradisionalitas: Menyoal Pesantren Assalafy. Yogyakarta: Arti Bumi Intaran.

Mahdun, Dede. 2015. Pengaruh Penerapan Metode Sorogan Terhadap Kemampuan Membaca Kitab Safinah Al-Najah Santri Putra Pemula (Usia 1315 Tahun) Pondok Pesantren Assalafie Babakan Ciwaringin Kabupaten Cirebon (skripsi). Cirebon: 
Jurusan Pendidikan Agama Islam Fakultas Tarbiyah dan Keguruan Institut Agama Islam Negeri (IAIN) Syekh Nurjati Cirebon.

Matry, Nurdin. 2008. ImplementasiDasar-Dasar Manajemen Sekolah Dalam Era Otonomi Daerah. Makassar: Aksara Madani YPM Pusat Makassar.

Muhaimin. 2007. Pengembangan Kurikulum Pendidikan agama Islam, di Sekolah, Madrasah, dan perguruan tinggi,Jakarta: PT Raja Grafindo Persada.

Ningsih, Vety. 2015. Pembelajaran Mata Pelajaran Fiqh Berbasis Kitab Kuning di SMP Ma'arif NU 2 Kemranjen Tahun Pelajaran 2014/2015 (skripsi). Purwokwrto: Jurusan Tarbiyah dan Keguruan Sekolah Tinggi Agama Islam Negeri Purwokwrto.

Parwis, Ahmad. 2012. Efektifitas Pembelajaran Kitab Kuning di Madrasah Aliyah Al-Islam Rumbo Kecamatan Kampar Kabupaten Kampar (skripsi). Pekanbaru: Fakultas Tarbiyah dan Keguruan Universitas Islam Negeri Sultan Syarif Kasim Riau.

Rahim Dkk,. 2001.Kendali Mutu Pendidikan Agama Islam.Jakarta: Departemen Agama RI Direktorat JenderalPembinaan Kelembagaan Agama Islam/ Direktorat Pembinaan Pendidikan Agama Islam pada Sekolah Umum Negeri, Proyek peningkatan tenaga teknis Pendidikan Agama Islam.

Rasyid, Ma'lum dan Idham. 2017. Saiyyang Pattuqduq dan Khataman Al Qur'an di Mandar. Yogyakarta: Zadahaniva Publishing.

Rijal, Akh. Syaiful. 2018. "Pemakaian Kitab Kuning Dalam Meningkatkan Mutu Pembelajaran Fiqh di Madrasah Tsanawiyah Berbasis Pesantren di Pamekasan", dalam jurnal Muslim Heritage, 1(2): 293-316.
Sa'adah, Nur. 2015. Implementasi Sistem Pembelajaran Kitab Kuning di Madrasah Diniyah Islam Slafiyah Jabalkat Sambijajar Sumbergempol Tulungagung (skripsi). Fakultas Tarbiyah dan Keguruan Institut Agama Islam Negeri Tulungagung.

Sholeh, Muhammad. 2014. Strategi Pembelajaran Kitab Kuning di Fakultas Agama Islam Universitas Al Washliyah (UNIVA) Medan (tesis): Medan: Program Pascasarjana Institut Agama Islam Negeri Medan.

Syaifullah. 2017. Analisis Penerapan Metode Bandongan dalam Pembelajaran Kitab Kuning di MA Plus Pondok Pesantren Abu Hurayrah Mataram (tesis). Mataram: Pascasarjana Institut Agama Islam Negeri Mataram.

Tafsir, Ahmad. 2007.Metodologi Pengajaran Agama Islam, Cetakan ke IX, Bandung: PT. Remaja Rosdakarya.

Taruna, Mulyana Mudis. 2012. "Standarisasi Penguasaan Kitab Kuning di Pondok Pesantren Nurul Hakim Nusa Tenggara Barat", dalam jurnal Analisa, 19(1): 107-119.

Taufik, Muhammad. 2016. Metode Pembelajaran Kitab Kuning di Pondok Pesantren Sunan Giri Krasak Kec. Argomulyo Kota Salatiga (skripsi). Salatiga: Fakultas Tarbiyah dan Keguruan Institut Agama Islam Negeri Salatiga.

Thoriqussu'ud, Muhammad. 2012. "Model-Model Pengemangan Kajian Kitab Kuning di Pondok Pesantren", dalam jurnal Ilmu Tarbiyah At-Tajdid, 1(2): 225-239.

Yumitro, Gonda dan Dion Maulana Prasetya. 2017. "Pesantren Resistance Against Cultural Globalization, dalam Jurnal Moqot, 41(2): 335360. 